\title{
ISOLATION, OPTIMIZATION, AND ANTITUMOR ACTIVITY OF L-ASPARAGINASE EXTRACTED \\ FROM PECTOBACTERIUM CAROTOVORUM AND SERRATIA MARCESCENS ON HUMAN BREAST ADENOCARCINOMA AND HUMAN HEPATOCELLULAR CARCINOMA CANCER CELL LINES
}

\author{
NOHA E ABDEL-RAZIK ${ }^{*}$, KHALED Z EL-BAGHDADY ${ }^{2}$, EINAS H EL-SHATOURY², NAHLA G MOHAMED ${ }^{3}$
}

${ }^{1}$ Department of Medical Laboratory Technology, College of Applied Medical Sciences, Jazan University, Kingdom of Saudi Arabia.

${ }^{2}$ Department of Microbiology, Faculty of Science, Ain Shams University, Cairo, Egypt. ${ }^{3}$ Egyvac, Vacsera, Giza, Egypt.

Email: nibrahim@jazanu.edu.sa

Received: 17 September 2018, Revised and Accepted: 30 November 2018

\section{ABSTRACT}

Objectives: The objective of this research was to obtain isolates capable of producing a high yield of L-asparaginase enzyme and to evaluate the antitumor activity of the purified enzyme against different cancer and normal cell lines.

Methods: Isolation of bacteria was performed by the serial dilution technique of soil samples collected from Cairo, Egypt, using modified M9 agar plates. Culture filtrates of selected isolates were quantitatively screened for L-asparaginase production using well-diffusion and direct nesslerization techniques. Factors influencing L-asparaginase activity were optimized by studying the effect of physical and nutritional conditions on the enzyme activity. The purification of L-asparaginase extracted from both the isolates was achieved using chilled acetone $\left(-20^{\circ} \mathrm{C}\right)$, followed by gel filtration on Sephadex G-100. The anticancer activity of the purified enzyme against human breast adenocarcinoma (MCF-7), human hepatocellular carcinoma (HepGII) and homo sapiens human (WISH) cell line was examined by 3-(4,5-dimethylthiazol-2-yl)-2,5 diphenyl tetrazolium bromide assay.

Results: Two L-asparaginase producers were identified by Biolog identification system as Pectobacterium carotovorum and Serratia marcescens. Optimization increased the production of L-asparaginase to 4.835 and $5.221 \mathrm{U} / \mathrm{ml}$ for P. carotovorum and $S$. marcescens, respectively. L-asparaginase was extracted, purified, and tested in vitro for cytotoxic activity using 3-(4,5-Dimethylthiazol-2-yl)-2,5 diphenyl tetrazolium bromide (MTT assay) against MCF-7, HepGII, and WISH cell line. L-asparaginase from P. carotovorum and S. marcescens was neutral to normal epithelial WISH cells. On the other hand, L-asparaginase from both isolates was cytotoxic to MCF-7 and HepGII cancer cell lines with an half maximal inhibitory concentration of 15 $\mu \mathrm{g} / \mathrm{ml}$ and $26 \mu \mathrm{g} / \mathrm{ml}$ and $26 \mu \mathrm{g} / \mathrm{ml}$ and $25 \mu \mathrm{g} / \mathrm{ml}$, respectively.

Conclusion: L-asparaginase extracted from P. carotovorum and S. marcescens showed remarkable anticancer activity. Further studies on hypersensitivity action need to be carried out to recommend the use of L-asparaginase as an alternative to commercially available preparations.

Keywords: L-asparaginase, Optimization, Cytotoxicity, Pectobacterium, Serratia.

(C) 2019 The Authors. Published by Innovare Academic Sciences Pvt Ltd. This is an open access article under the CC BY license (http://creativecommons. org/licenses/by/4. 0/) DOI: http://dx.doi.org/10.22159/ajpcr.2019.v12i2.29646

\section{INTRODUCTION}

L-asparaginase is relatively widespread enzyme found in bacteria, yeast, fungi, and plants. It catalyzed the hydrolysis of the amide group of asparagine to yield aspartate and ammonia [1]. Many reports demonstrated the anti-leukemic activity of L-asparaginase [2-4]. Today, L-asparaginase is an essential drug that is used in the treatment of acute lymphoblastic leukemia in children all over the world. ELSPAR, ONCASPAR, KIDROLASE, and ERWINASE are the brand name of L-asparaginase used as drug [5]. The antitumor activity of L-asparaginase was believed to be because most neoplastic tissues require their exogenous supply of L-asparagine from circulating pools because of the absence of L-asparagine synthetase. On the other hand, normal cells synthesize L-asparagine in sufficient quantities for protein synthesis within the cell by L-asparagine synthetase from aspartic acid and glutamine or can be absorb available L-asparagine from the cell surrounding. L-asparaginase breakdowns the circulating asparagine to L-aspartate and ammonia and prevents protein synthesis of neoplasms. Therefore, the most common therapeutic practice to treat this condition is to intravenously administer L-asparaginase to deplete the blood L-asparagine level and exhaust its supply to selectively affect the neoplastic cells [6].

Microbial sources are very common and convenient for L-asparaginase production since they can be easily cultured and produced compounds that could be extracted and purified, as a result facilitating the industrial scale production [7]. The most commonly used microorganisms to produce L-asparaginase were Escherichia coli, Bacillus sp., Streptomyces albidoflavus, and actinomycetes from the rhizosphere of medicinal plants [8]. L-asparaginase from E. coli and Erwinia chrysanthemi has a perfect action to inhibit the activity of tumor cells. They were clinically used as effective drugs in the treatment of Hodgkin's disease, acute myelocytic leukemia, acute myelomonocytic leukemia, chronic lymphocytic leukemia, lymphosarcoma, reticulosarcoma, and melanosarcoma [9]. However, L-asparaginase from these two bacterial sources caused hypersensitivity in the long term leading to mild allergic reactions to anaphylactic shock [10]. E. chrysanthemi L-asparaginase exhibited less allergic reactions compared to the $E$. coli enzyme. However, Erwinia (synonym: Pectobacterium) [11,12] L-asparaginase had a shorter half-life than E. coli [13]. This advocated the need to discover new L-asparaginases with less adverse effects but has similar therapeutic effects. Therefore, the aim of this work was to obtain isolates capable of producing a high yield of L-asparaginase enzyme and to evaluate the antitumor activity of the purified enzyme against different human cell lines.

\section{METHODS}

Detection and screening L-asparaginase-producing bacteria Isolation of bacteria was performed by the serial dilution technique of two soil samples collected from two sites from Cairo, Egypt, into sterile bottles at a depth of 30-40 cm, using modified M9 agar plates 
containing $5 \mu \mathrm{g} / \mathrm{ml}$ of nystatin as an antifungal agent and supplemented with $0.09 \%$ phenol red (prepared in ethanol) as indicator. The $\mathrm{pH}$ was adjusted to 6.2 using $1 \mathrm{~N} \mathrm{HCl}$. M9 medium plates without both indicator and asparagine served as controls (instead containing $\mathrm{NaNO}_{3}$ as nitrogen source) were also prepared. After incubation at $37^{\circ} \mathrm{C}$ for $48 \mathrm{~h}$, colonies with pink zones were considered as L-asparaginase-producing bacteria.

Culture filtrates of selected isolates were semi-quantitatively screened for L-asparaginase production using well diffusion technique. Sterile Erlenmeyer flasks $(250 \mathrm{ml})$ containing $50 \mathrm{ml}$ sterile modified asparagine M9 broth medium were inoculated with $1 \mathrm{ml}\left(10^{6}\right.$ colony-forming unit [CFU]) of each isolate that showed production of L-asparaginase. Flasks were incubated at $37^{\circ} \mathrm{C}$ for $24 \mathrm{~h}$ in a rotatory shaking incubator at 120 revolutions per minute (rpm) [14].

Wells (5-mm diameter) were made using sterilized cork borer in the center of modified M9 agar plate, and then, $50 \mu \mathrm{l}$ of broth culture was transferred to each well. After incubation at $37^{\circ} \mathrm{C}$ for $24 \mathrm{~h}$, the diameter of pink zones around the wells was measured and recorded [14].

\section{Identification of bacterial isolates}

The preliminary identification of potential isolates was performed according to Bergey's Manual of Systematic Bacteriology [15]. Identification of the potent isolates was carried out by Biolog System (GEN III identification) EGYVAC - VACSERA, Giza, Egypt.

\section{Assay of L-asparaginase}

An overnight inoculum $(1 \mathrm{ml})$ of bacterial suspension $\left(10^{6} \mathrm{CFU}\right)$ was transferred to $250 \mathrm{ml}$ Erlenmeyer flasks with $50 \mathrm{ml}$ broth modified M9 medium and incubated in a shaking incubator $(120 \mathrm{rpm})$ at $37^{\circ} \mathrm{C}$ for $24 \mathrm{~h}$. After incubation, bacterial cells were removed by centrifugation at $10,000 \mathrm{rpm}$ for $10 \mathrm{~min}$ at $4^{\circ} \mathrm{C}$ [16]. The supernatant was used to assay extracellular L-asparaginase activity which was measured by Nessler's reaction (Direct Nesslerization of ammonia) according to Mashburn and Wriston [17]. The blank was prepared by mixing distilled water with Nessler's reagent. The concentration of ammonia was estimated and the absorbance was measured at $450 \mathrm{~nm}$, using spectrophotometer (Thermo scientific). A standard curve was drawn with various concentrations of ammonia.

\section{Optimization of L-asparaginase production}

Factors influencing L-asparaginase activity were optimized by studying the effect of physical and nutritional conditions on the enzyme activity. The optimal condition identified for each parameter was applied for optimizing the next one.

Optimization of different environmental conditions (incubation temperature, $\mathrm{pH}$, and incubation period) for $\mathrm{L}$-asparaginase production

The optimum temperature for maximum L-asparaginase production was determined by incubating the cultures at different temperatures from 25 to $40^{\circ} \mathrm{C}$ with an interval of $5^{\circ} \mathrm{C}$ on $\mathrm{M} 9$ media for $24 \mathrm{~h}$. To detect the optimum $\mathrm{pH}$ for the production of L-asparaginase, media were adjusted at different $\mathrm{pH}$ values $(6.5,7.0,7.5$, and 8.0$)$ using $1 \mathrm{~N} \mathrm{NaOH} / 1 \mathrm{~N}$ $\mathrm{HCl}$. The effect of incubation period on L-asparaginase production by the bacterial cultures was determined by incubating for $24,48,72$, and 120 h. For each parameter, bacterial isolates were grown on M9 broth medium and the cultures supernatants were assayed as described (2.3) [18]. The optimal condition identified for each parameter was applied for optimizing the next one.

Optimization of different nutritional factors (carbon and nitrogen sources) for L-asparaginase production

The addition of different carbon and nitrogen sources other than glucose and L-asparagine was made separately in the medium, to enhance enzyme production such as sucrose, maltose, and lactose and yeast extract, peptone, and ammonium nitrate at $1 \%(\mathrm{w} / \mathrm{v})$ according to Indira et al. [19].
Purification of L-asparaginase

The culture filtrate was filtered through Whatman No. 1 filter paper $(0.22 \mu)$ and centrifuged at $8000 \mathrm{rpm}$ for $10 \mathrm{~min}$ at $4^{\circ} \mathrm{C}$. Chilled acetone $\left(-20^{\circ} \mathrm{C}\right)$ was added to the culture filtrate (crude enzyme) with constant stirring at $4^{\circ} \mathrm{C}$ in the gradient concentration of $4: 1$, for proteins to precipitate. The precipitated proteins were centrifuged and air dried then dissolved in $0.01 \mathrm{M}$ phosphate buffer ( $\mathrm{pH}$ 8.5).

The concentrated enzyme was applied to diethylaminoethyl cellulose column $(4 \mathrm{~cm} \times 60 \mathrm{~cm})$ equilibrated with $50 \mathrm{mM}$ Tris-HCl $(\mathrm{pH}-8.6)$. The column was washed with two volumes of starting buffer, and the protein was eluted with linear gradient of $\mathrm{NaCl}(0-0.5 \mathrm{M})$ prepared in phosphate buffer $\mathrm{pH} 7.4$ at the rate of $60 \mathrm{ml} / \mathrm{h}$. Fractions showing L-asparaginase activity were pooled together dialyzed against $50 \mathrm{mM}$ Tris- $\mathrm{HCl}$ (pH8.6) and concentrated with bench top protein concentrator at $4^{\circ} \mathrm{C}$.

The concentrated enzyme solution was added on the top of Sephadex G-100 column $(4 \mathrm{~m} \times 60 \mathrm{~cm})$ equilibrated with $50 \mathrm{mM}$ Tris- $\mathrm{HCl}(\mathrm{pH} 8.6)$ and eluted with the same buffer at the flow rate of $0.5 \mathrm{ml} / \mathrm{min}$. Fractions showing L-asparaginase activity were pooled and dialyzed against the same buffer and lyophilized with bench top lyophilizer [20].

Determination of the molecular weight of the purified enzyme by sodium dodecyl sulfate polyacrylamide gel electrophoreses (SDS-PAGE)

The molecular weight of the extracted enzyme was determined by performing SDS-PAGE according to the method of Laemmli [21], using protein marker of 10-260 KDa (Thermo Fischer Scientific).

\section{Cytotoxicity assay}

\section{Cell lines}

Three cell lines: Human breast adenocarcinoma (MCF-7; ATCC number: HTB-22), human hepatocellular carcinoma (HepGII; ATCC number: HB-8065), and Homo sapiens human (WISH, HeLa contaminant; ATCC number: CCL-25) were obtained from EGYVAC-VACSERA, Giza, Egypt.

Cell viability determined by 3-(4,5-Dimethylthiazol-2-yl)-2,5 diphenyl tetrazolium bromide (MTT) method

Each of the three cell lines, MCF-7, HepGII, and WISH, were seeded at $2 \times 10^{4}$ cells/well in tissue culture plates and incubated at $37^{\circ} \mathrm{C}$ for $24 \mathrm{~h}$. For background absorption, some wells were remained cell free as blank control. The L-asparaginase was added to the cells at serial concentrations of $100,50,25,12.5$, and $6.25 \mu \mathrm{g} / \mathrm{ml}$, and the control was also included (without $\mathrm{L}$-asparaginase). The final volume was adjusted to $100 \mu \mathrm{l} /$ well. The plates were incubated overnight at $37^{\circ} \mathrm{C}, 5 \% \mathrm{CO}_{2} .25 \mu \mathrm{l}$ of $(0.5 \mathrm{mg} /$ $\mathrm{ml}$ ) MTT stain was added to each well, and the plates were incubated at $37^{\circ} \mathrm{C}$ for $4 \mathrm{~h} .100 \mu \mathrm{l}$ of dimethyl sulfoxide (DMSO) stop solution was added to each well. The plates were shaken at room temperature for 30 min- $1 \mathrm{~h}$. The plates were then read using ELISA Microplate reader at $570 \mathrm{~nm}$. The percentage of viable cells was calculated from the formula:

Survival fraction=OD of treatment cell/OD of control cell.

The half maximal inhibitory concentration $\left(\mathrm{IC}_{50}\right.$ ) was calculated by fitting the survival curve using GraphPad Prism software in corporate [22].

\section{Morphological characteristics of cell lines}

MCF-7 and HepGII cells were cultured in 6-well plates. L-asparaginase extracted from the selected isolates was added for medium at a concentration of IC ${ }_{50}(15 \mu \mathrm{g} / \mathrm{ml}$ and $26 \mu \mathrm{g} / \mathrm{ml}$ and $26 \mu \mathrm{g} / \mathrm{ml}$ and $25 \mu \mathrm{g} / \mathrm{ml}$, respectively). After treatment, all the cultures were incubated at $37^{\circ} \mathrm{C}$, $5 \% \mathrm{CO}_{2}$ for $24 \mathrm{~h}$, then were washed well with phosphate buffered saline, and fixed in $10 \%$ neutral formalin for $24 \mathrm{~h}$. Photographs were taken under an inverted Leica fluorescence $40 \times 10$ microscope [23]

\section{Statistical analysis}

All statistical analyses in this study were carried out using Microsoft Excel 2000, Analysis Tool pack (Microsoft Corporation). All data were 
calculated from at least 3 replicates, and the standard error for each datum was plotted on the graph.

\section{RESULTS AND DISCUSSION}

Selection and identification of potent L-asparaginase-producing bacteria

Fifty-three colonies randomly selected were purified and subcultured on modified M9 agar media supplemented with $0.09 \%$ phenol red to confirm their production of L-asparaginase. Only nine isolates which showed pink color around the colonies confirming their production of L-asparaginase were selected. The ability of the production of L-asparaginase was based on the color change due to a change in $\mathrm{pH}$ of the medium. Asparaginase causes the hydrolysis of L-asparaginase into L-aspartic acid and ammonia. The release of ammonia changes $\mathrm{pH}$ due to phenol red indicator; it has a pale yellow color with the acidic condition, as the $\mathrm{pH}$ changes to alkaline it turns to pink [24]. According to well diffusion agar assay, two bacterial isolates, FS-4 and GS-7, that showed larger zone of pink color $(5.2 \mathrm{~cm} \pm 0.005$ and $4.5 \mathrm{~cm} \pm 0.005$, respectively) were selected (Fig. 1). Similar diameters were recorded by Upadhyay et al. [25]. Smaller diameter in the range of $1.9 \mathrm{~cm}, 1.0 \mathrm{~cm}$, and $0.8 \mathrm{~cm}$ was reported by Jain et al. [26] and Patil and Jadhav [27].

The two isolates FS-4 and GS-7 were identified using the Biolog identification System as Pectobacterium carotovorum and Serratia marcescens, respectively.

\section{Production of L-asparaginase by $P$. carotovorum and $S$. marcescens} isolates

P. carotovorum and $S$. marcescens were used to produce L-asparaginase enzyme on modified M9 broth media. The enzyme activities were $4.497 \mathrm{U} / \mathrm{ml} \pm 0.009$ and $4.238 \mathrm{U} / \mathrm{ml} \pm 0.007$, while the specific activities were found to be $6.424 \mathrm{U} / \mathrm{ml}$ and $8.476 \mathrm{U} / \mathrm{ml}$ for P. carotovorum and S. marcescens, respectively.

\section{Effect of incubation temperature on L-asparaginase production}

The bacterial isolates were incubated at four different temperatures $\left(25,30,35\right.$, and $\left.40^{\circ} \mathrm{C}\right)$. The results showed thst the best incubation temperature was $35^{\circ} \mathrm{C}$ for $P$. carotovorum and $30^{\circ} \mathrm{C}$ for $S$. marcescens which gave activity $4.494 \mathrm{U} / \mathrm{ml} \pm 0.09$ and $4.503 \mathrm{U} / \mathrm{ml} \pm 0.09$, respectively, as shown in Fig. 2. Similar temperature range was reported by previous studies carried out by Jha et al. [28] who reported that $37^{\circ} \mathrm{C}$ was the optimal temperature for maximum activity by Pseudomonas fluorescens. Prakasham et al. [29] and Ghosh et al. [30] produced L-asparaginase at $30^{\circ} \mathrm{C}$ by $S$. marcerens and Staphylococcus sp., respectively, Similarly, Manna et al. [31] isolated L-asparaginase from Pseudomonas stutzeri under the same temperature. Temperature is a critical factor which has to be controlled and has to be optimized. Previous studies have validated that the enzyme metabolism of microorganisms represented an important pathway for survival and in turn depends on the incubation temperature [32].

\section{Effect of initial $\mathbf{p H}$ on L-asparaginase production}

Four initial medium $\mathrm{pH}$ values $(6.5,7.0,7.5$, and 8.0$)$ were used to increase the L-asparaginase production by P. carotovorum and $S$. marcescens isolates. The results indicated that the P. carotovorum and $S$. marcescens isolates preferred the neutral $\mathrm{pH}$ value 7 and 7.5 and gave an activity of $4.497 \mathrm{U} /$ $\mathrm{ml} \pm 0.08$ and $4.443 \mathrm{U} / \mathrm{ml} \pm 0.04$, respectively (Fig. 3). This result is similar to that obtained by Narayana et al. [33] for maximum L-asparaginase production from S. albidoflavus at pH 7.0. Kumar et al. [34] also reported maximum L-asparaginase production from $S$. marcescens at $\mathrm{pH} 7.5$. On the other hand, Akilandeswari et al. [35] and Neelima et al. [36] found that the maximum L-asparaginase production from Streptomyces ginsengisoli was at $\mathrm{pH} 9.0$.

\section{Effect of incubation period on L-asparaginase production}

The bacterial isolates were incubated at four different periods $(24,48$, 72 , and $120 \mathrm{~h}$ ). The results showed that the best incubation period was $48 \mathrm{~h}$ for both $P$. carotovorum and $S$. marcescens which gave activity 4.44 $\mathrm{U} / \mathrm{ml} \pm 0.05$ and $4.49 \mathrm{U} / \mathrm{ml} \pm 0.04$, respectively (Fig. 4). These findings were comparable to that described by Kumar et al. [34] who reported that the maximum L-asparaginase activity was observed at $48 \mathrm{~h}$. After $48 \mathrm{~h}$, it was decreased due to the depletion of nutrient materials.

\section{Effect of carbon sources on L-asparaginase production}

Four carbon sources, namely glucose, sucrose, maltose, and lactose, were applied to enhance the L-asparaginase production by $P$. carotovorum and S. marcescens isolates. The results concluded that the lactose was the best carbon source for L-asparaginase production by $P$. carotovorum $(4.802 \mathrm{U} / \mathrm{ml} \pm 0.03)$, while the sucrose sugar was the best one for $S$. marcescens ( $5.00 \mathrm{U} / \mathrm{ml} \pm 0.06$ ) (Fig. 5). Stanbury et al. [37]

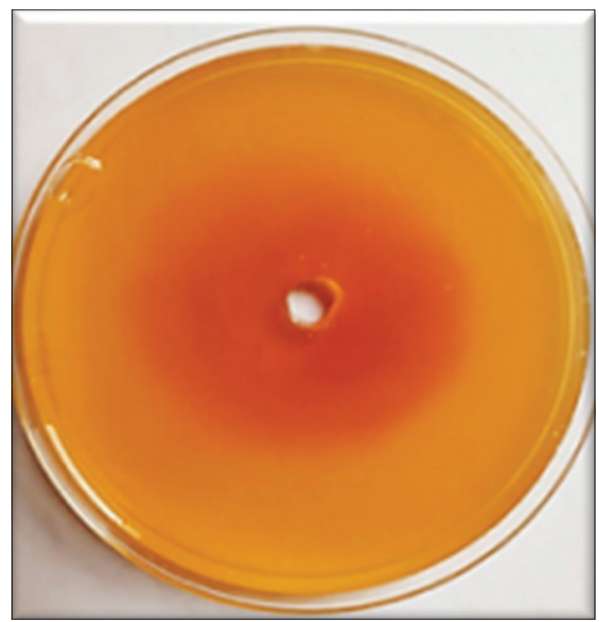

Fig. 1: Field study-4 isolate showed highest L-asparaginase production

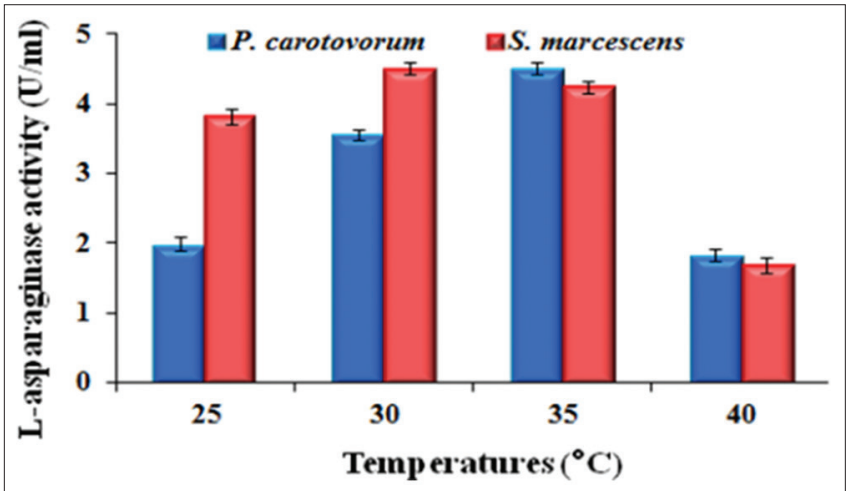

Fig. 2: L-asparaginase production by Pectobacterium carotovorum and Serratia marcescens isolates under different incubation temperatures

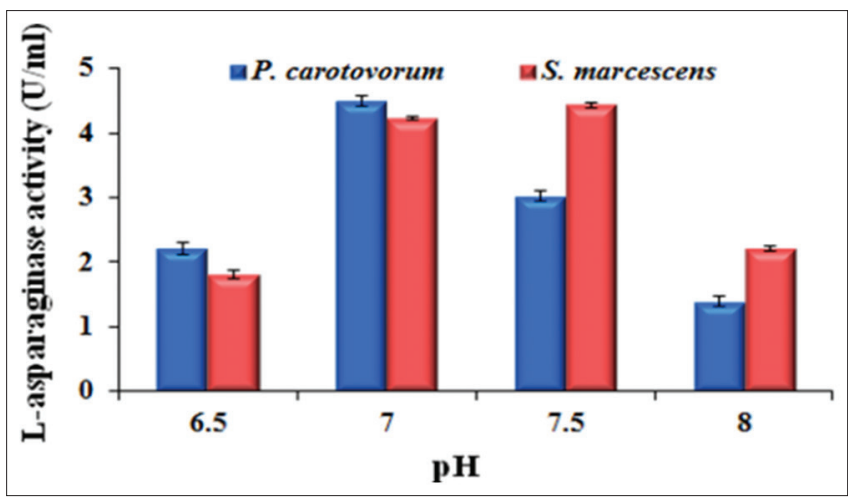

Fig. 3: L-asparaginase production by Pectobacterium carotovorum and Serratia marcescens isolates under different $\mathrm{pH}$ values 
stated that carbohydrates are used as carbon sources in the microbial fermentation processes. Kumar et al. [34] observed higher titers of L-asparaginase by $S$. marcescens when the medium was supplemented with $1.5 \%$ sucrose. Susmita and Mandal [38] reported sucrose as the best carbon source for L-asparaginase production. This may be due to the inductive effect of sucrose and its efficiency in asparaginase production, and it also helps in stabilizing the enzyme [39]. In contrary, El Shobaky et al. [40] indicated that the maximum L-asparaginase production was recorded in the presence of lactose as carbon source followed by maltose and fructose than sucrose. Lactose was reported as the best carbon source under aerobic conditions for the synthesis of L-asparaginase by Staphylococcus sp. [29]. However, Varalakshmi [41] reported a decline in L-asparaginase production on supplementation with fructose and a highest L-asparaginase activity by Staphylococcus sp. when supplemented with maltose.

\section{Effect of nitrogen sources on L-asparaginase production}

In this study, asparagine as the main nitrogen source was changed by yeast extract, ammonium nitrate, and peptone to enhance the L-asparaginase production by $P$. carotovorum and S. marcescens isolates. The results showed that the best nitrogen source was ammonium nitrate for P. carotovorum (4.839 $\mathrm{U} / \mathrm{ml} \pm 0.03$ ) and asparagine for $S$. marcescens (4.238 U/ml \pm 0.03 ) (Fig. 6). Our results agreed with El Shobaky et al. [40] who showed that ammonium nitrate was the most suitable nitrogen source for optimum L-asparaginase production followed by urea and sodium nitrate. Maximal production of L-asparaginase varied by varying the nitrogen source. Athira et al. [42] indicated sodium nitrate as best nitrogen source. However, Narayana et al. [33] indicated yeast extract to be best nitrogen source and Neelima et al. [36] used peptone as the best nitrogen source.

Production of L-asparaginase by $P$. carotovorum and $S$. marcescens isolates under optimum conditions

Optimization of conditions yields an increase in the production of L-asparaginase enzyme of $7.5 \%$ (from $4.497 \mathrm{U} / \mathrm{ml}$ to $4.835 \mathrm{U} /$ $\mathrm{ml}$ ) by $P$. carotovorum and $23 \%$ (from $4.238 \mathrm{U} / \mathrm{ml}$ to $5.221 \mathrm{U} / \mathrm{ml}$ ) by $S$. marcescens, and the specific activity was reached to 6.9 and $10.4 \mathrm{U} / \mathrm{ml}$ with $P$. carotovorum and $S$. marcescens, respectively (Fig. 7).

\section{Isolation and purification of L-asparaginase enzyme}

L-asparaginase enzyme produced by $P$. carotovorum and $S$. marcescens isolates under optimum conditions was isolated from free cells supernatants by precipitation. After purification, the molecular weight and purity of the L-asparaginase enzyme was assessed by running through electrophoresis SDS-PAGE. The purified L-asparaginase enzyme had a molecular weight of $35 \mathrm{kDa}$ for $P$. carotovorum and $36 \mathrm{kDa}$ for $S$. marcescens isolates (Fig. 8). L-asparaginase from different sources showed close molecular weights: Mohamed [43] reported that the molecular weight of L-asparaginase from E. coli was $33 \mathrm{kDa}$. Prista and Kyridio [44] indicated that $E$. coli L-asparaginase had molecular weight value $33 \mathrm{kDa}$. On the other hand, Jain et al. [26] found that the molecular weight of purified L-asparaginase obtained from E. coli VRY-15 was $56 \mathrm{KDa}$ which was different from that of commercially available L-asparaginase having a molecular weight of $31.73 \mathrm{KDa}$.

In vitro cytotoxicity assay of $P$. carotovorum and $S$. marcescens produced L-asparaginase on MCF-7, HepGII, and WISH cell lines

\section{Cell viability determined by MTT assay}

Cell viability results of L-asparaginase enzyme obtained from P. carotovorum and $S$. marcescens isolates are summarized in Tables 1 and 2. Cell viability of WISH cell line treated with L-asparaginase extracted from both isolates increased by the increase of enzyme concentration. No cytotoxic effect was observed for normal epithelial WISH cell line when treated with purified L-asparaginase. Bhat and Marar [45] reported that the purified enzyme did not exhibit any effect on normal human lymphocytes, implying that it may prove to be a novel source for L-asparaginase isolated for chemotherapeutic purpose.
The incubation of $M C F-7$ cell line with the increasing concentration of L-asparaginase enzyme caused a gradual inhibition of cell growth as observed from its low $\mathrm{IC}_{50}$ value $15 \mu \mathrm{g} / \mathrm{ml}$ and $26 \mu \mathrm{g} / \mathrm{ml}$ with L-asparaginase from $P$. carotovorum and $S$. marcescens, respectively. However, the L-asparaginase purified from $S$. marcescens isolate showed better toxicity on HepGII cell line (7.53\% survival) in comparison to L-asparaginase produced by $P$. carotovorum isolate (29.81\% survival). The sensitivity of the cell line to both L-asparaginases (purified from both the isolates) appeared to be dose dependent, resulting in the significant decrease in viable cells.

Similarly, it was reported that the purified L-asparaginase from Erwinia caratovora significantly increased the number of apoptotic cells to $40 \%$ (Jurkat cells) and 99\% (HL60 cells), suggesting that the enzyme

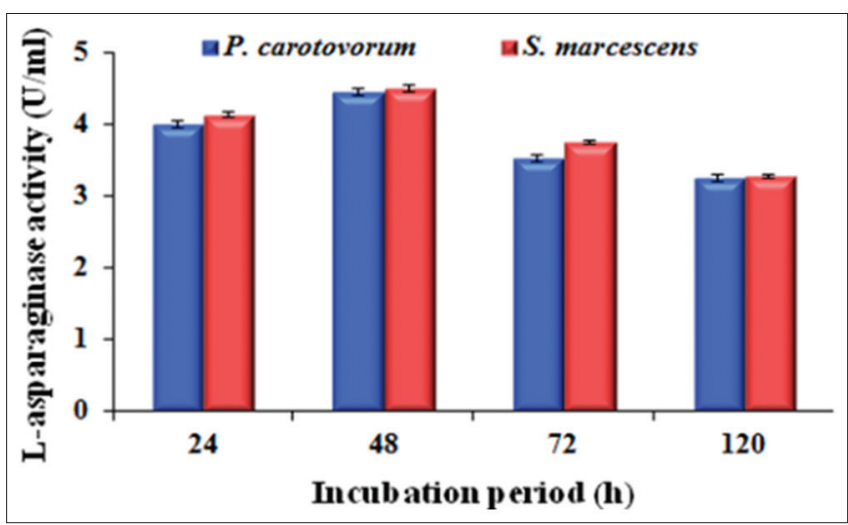

Fig. 4: L-asparaginase production by Pectobacterium carotovorum and Serratia marcescens isolates under different incubation periods

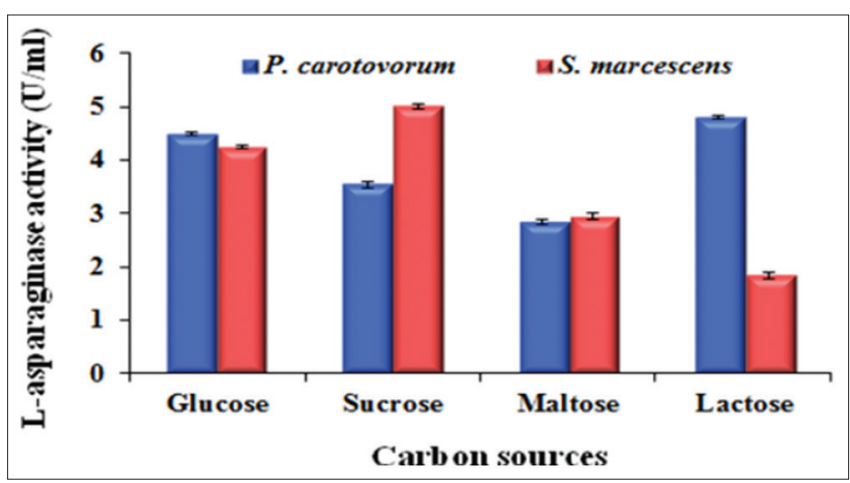

Fig. 5: L-asparaginase production by Pectobacterium carotovorum and Serratia marcescens strains under different carbon sources

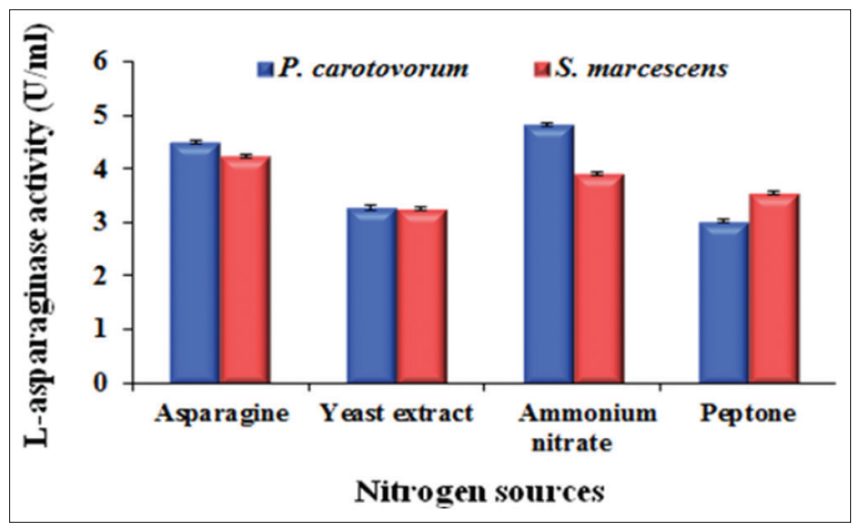

Fig. 6: L-asparaginase production by Pectobacterium carotovorum and Serratia marcescens isolates under different nitrogen sources 


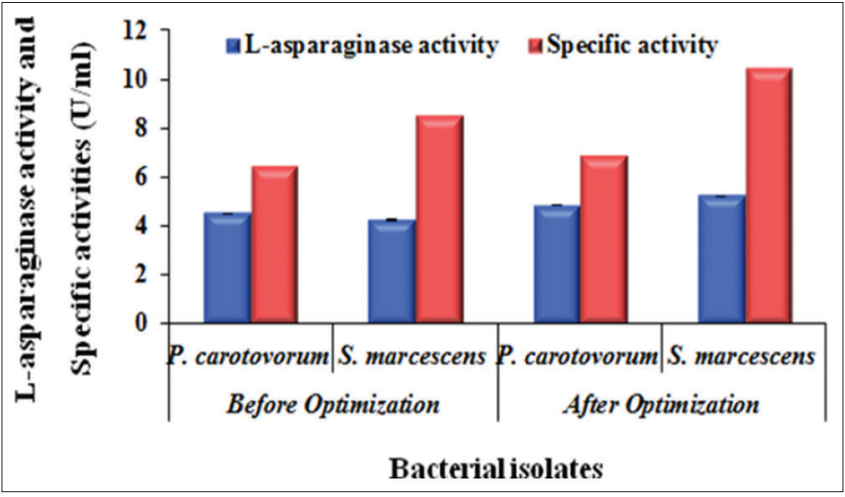

Fig. 7: L-asparaginase activity and specific activities $(\mathrm{U} / \mathrm{ml})$ produced by Pectobacterium carotovorum and Serratia marcescens isolates before and after optimization

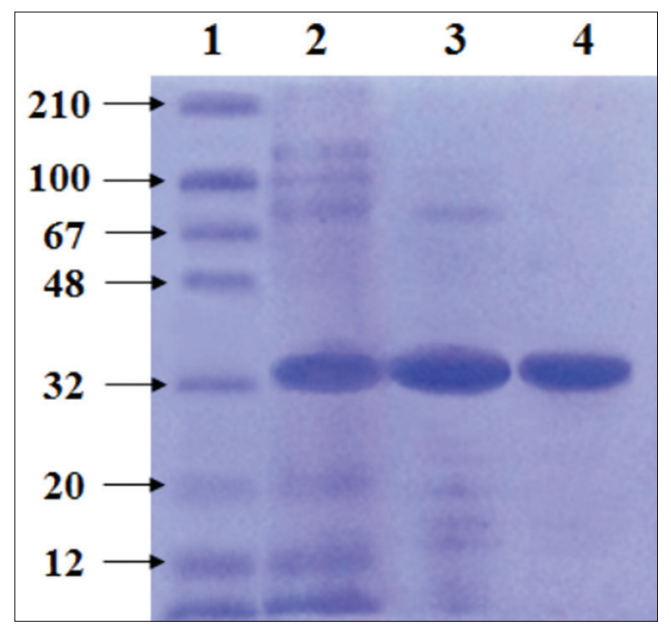

Fig. 8: Sodium dodecyl sulfate polyacrylamide gel electrophoreses of purified L-asparaginase enzyme from Serratia marcescens isolate. Lane 1: Protein marker (10-260 KDa, Thermo Fischer Scientific), 2: Ammonium sulfate precipitation, 3: Diethylamino ethyl cellulose purification, and 4: Sephadex purification

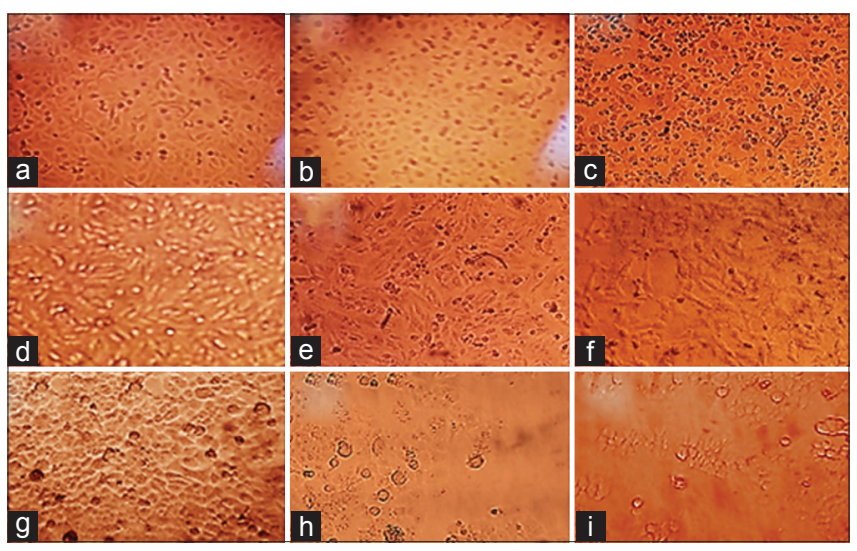

Fig. 9: Photomicrographs of morphological changes for human breast adenocarcinoma (MCF-7), human hepatocellular carcinoma (HepGII), homo sapiens human cells in response to L-asparaginase extracted from Serratia marcescens and Pectobacterium carotovorum at $\times 4010$ magnification microscopy. (a, d, and g) MCF-7, HepGII, and WISH cells (control); and (b, e, and H): MCF-7, HepGII, and WISH cells treated with $\mathrm{L}$-asparaginase from $S$. marcescens, respectively. (c, f, and i) MCF-7, HepGII, and WISH cells treated with L-asparaginase from P. carotovorum, respectively
Table 1: Efficacy of $P$. carotovorum L-asparaginase on cell viability relative to its concentration

\begin{tabular}{llll}
\hline $\begin{array}{l}\text { Concentration } \\
(\boldsymbol{\mu g} / \mathrm{ml})\end{array}$ & \multicolumn{3}{l}{$\begin{array}{l}\text { \% of cell viability after the application of } \\
\text { P. carotovorum L-asparaginase }\end{array}$} \\
\cline { 2 - 4 } & $\boldsymbol{M C F - 7}$ & HepGII & WISH \\
\hline 0 & $100 \pm 0.008$ & $100 \pm 0.002$ & $100 \pm 0.002$ \\
6.25 & $82.253 \pm 0.005$ & $58.201 \pm 0.030$ & $100.301 \pm 0.001$ \\
12.5 & $55.310 \pm 0.009$ & $56.790 \pm 0.007$ & $98.979 \pm 0.002$ \\
25 & $32.124 \pm 0.005$ & $51.146 \pm 0.025$ & $96.396 \pm 0.004$ \\
50 & $31.735 \pm 0.001$ & $32.275 \pm 0.001$ & $90.090 \pm 0.001$ \\
100 & $26.683 \pm 0.004$ & $29.806 \pm 0.001$ & $80.829 \pm 0.005$ \\
$\mathrm{IC}_{50}$ & $15 \mu \mathrm{g} / \mathrm{ml}$ & $26 \mu \mathrm{g} / \mathrm{ml}$ & $100 \mu \mathrm{g} / \mathrm{ml}$ \\
\hline
\end{tabular}

MCF-7: Human breast adenocarcinoma, HepGII: Human hepatocellular carcinoma, WISH: Homo sapiens human, $P$. carotovorum: Pectobacterium carotovorum, $\mathrm{IC}_{50}$ : Half maximal inhibitory concentration

Table 2: Efficacy of $S$. marcescens L-asparaginase on cell viability relative to its concentration

\begin{tabular}{llll}
\hline $\begin{array}{l}\text { Concentration } \\
(\boldsymbol{\mu g} / \mathbf{m l})\end{array}$ & \multicolumn{3}{l}{$\begin{array}{l}\text { \% of cell viability after application of } \\
\text { S. marcescens } \text { L-asparaginase }\end{array}$} \\
\cline { 2 - 4 } & $\boldsymbol{M C F - 7}$ & HepGII & WISH \\
\hline 0 & $100 \pm 0.124$ & $100 \pm 0.284$ & $100 \pm 0.002$ \\
6.25 & $81.122 \pm 0.077$ & $80.607 \pm 0.189$ & $100.541 \pm 0.002$ \\
12.5 & $59.777 \pm 0.099$ & $60.846 \pm 0.068$ & $99.879 \pm 0.006$ \\
25 & $50.805 \pm 0.105$ & $49.329 \pm 0.074$ & $93.213 \pm 0.003$ \\
50 & $45.372 \pm 0.058$ & $38.993 \pm 0.094$ & $81.802 \pm 0.015$ \\
100 & $46.135 \pm 0.037$ & $7.532 \pm 0.066$ & $64.865 \pm 0.004$ \\
$\mathrm{IC}_{50}$ & $26 \mu \mathrm{g} / \mathrm{ml}$ & $25 \mu \mathrm{g} / \mathrm{ml}$ & $100 \mu \mathrm{g} / \mathrm{ml}$ \\
\hline
\end{tabular}

S. marcescens: Serratia marcescens, MCF-7: Human breast adenocarcinoma,

HepGII: Human hepatocellular carcinoma, WISH: Homo sapiens human

cytotoxicity is associated with only L-asparagine deficiency [46]. L-asparaginase enzyme was tested against three different cell lines for its anticancerous activity, human cancer colon Caco-2, human breast cancer $M C F-7$, and human cancer prostate $p c-3$. The enzyme showed anticancer activity against $M C F-7$ and $p c-3$, where it was non-effective to the cell line Caco-2 [43].

Morphological changes of MCF-7, HepGII, and WISH cell lines induced by L-asparaginase

The effect of L-asparaginase extracted from $S$. marcescens and P. carotovorum was evaluated on MCF-7, HepGII, and WISH cell morphology using the calculated $\mathrm{IC}_{50}$ values previously reported. The morphological changes were observed using inverted phase-contrast microscopy. The control MCF-7, HepGII, and WISH cells (treated only with DMSO) showed the normal morphology of cobblestone-like appearance with strong cell-cell adhesion, monotonous spindleshaped cells containing single round nuclei with flattened cytoplasm, and epithelioid amnion cells that grow in a closely apposed monolayer, respectively (Fig. 9a,d and g).

Results demonstrated that both MCF-7 and HepGII cells treated with L-asparaginase extracted from $S$. marcescens and P. carotovorum showed shrinkages, dispersing, and irregularity in shape, rounding cells, and complete detachments of cells from the surface and loss of cytoplasmic vacuole (Fig. 9b,c,e and f), while WISH cell have no morphological changes induced by L-asparaginase extracted from both P. carotovorum and $S$. marcescens isolates (Fig. $9 \mathrm{~h}$ and i).

\section{AUTHORS' CONTRIBUTIONS}

The majority of the experimental work was performed by Noha E. Abdel-Razik. All authors contributed equally to conduct this work, idea, protocol, consultancy, writing, and review the article. 


\section{CONFLICTS OF INTEREST}

All authors have none to declare.

\section{REFERENCES}

1. Kumar K, Verma N. The various sources and application of L-asparaginase. Asian J Biochem Pharm Res 2012;3:197-205.

2. Deokar VD, Vetal MD, Rodrigues L. Production of intracellular L-asparaginase from Erwinia carotovora and its statistical optimization using response surface methodology (RSM). Int J Chem Sci Appl 2010;1:25-36.

3. Savitri NA, Azmi W. Microbial L-asparaginase: A potent antitumour enzyme. Indian J Biotechnol 2003;2:184-94.

4. Theantana T, Hyde T, Lymyong S. Asparginase production by endophytic fungi from Thai medicinal plants: Cytotoxicity properties. Int J Integr Biol 2009;7:1-8.

5. Jha SK, Pasrija D, Sinha RK, Singh HR. Microbial L-asparaginase: A review on current scenario and future prospects. Int J Pharm Sci Res 2012;3:3076-90.

6. Warangkar SC, Khobragade CN. Purification, characterization, and effect of thiol compounds on activity of the Erwinia carotovora L-asparaginase. Enzyme Res 2010;1:1-10.

7. Verma N, Kumar K, Kaur G, Anand S. L-asparaginase: A promising chemotherapeutic agent. Crit Rev Biotechnol 2007;27:45-62.

8. Cedar H, Schwartz JH. Production of L-asparaginase II by Escherichia coli. J Bacteriol 1968;96:2043-8.

9. Bansal S, Gnaneswari D, Mishra P, Kundu B. Structural stability and functional analysis of L-asparaginase from Pyrococcus furiosus. Biochemistry (Mosc) 2010;75:375-81.

10. Narta UK, Kanwar SS, Azmi W. Pharmacological and clinical evaluation of L-asparaginase in the treatment of leukemia. Crit Rev Oncol Hematol 2007;61:208-21.

11. Kwon SW, Go SJ, Kang HW, Ryu JC, Jo JK. Phylogenetic analysis of erwinia species based on 16S rRNA gene sequences. Int J Syst Bacteriol 1997; 47:1061-7.

12. Euze' J. Notification that new names and new combinations have appeared in volume 53, part 2, of the IJSEM. Int J Syst Evol Microbiol 2003;53:939-40.

13. Asselin BL, Whitin JC, Coppola DJ, Rupp IP, Sallan SE, Cohen HJ, et al. Comparative pharmacokinetic studies of three asparaginase preparations. J Clin Oncol 1993;11:1780-6.

14. Rajagopal SV, Talluri V, Bhavana M. Isolation and screening of L-asparaginase producing bacteria from Visakhapatnam soil samples. Int J Pharm Chem Biol Sci 2013;3:1121-5.

15. Hold JG. Facultative anaerobic gram-negative rad. In: Bergey's Manual of Determinative Bacteriology. $9^{\text {th }}$ ed. Philadelphia, PA: Williams and Wilkins; 1994.

16. Ren J, He F, Zhang L. The construction and application of a new PPY-MSPQC for L-asparaginase activity assay. Sens Actuators 2010;145:272-7.

17. Mashburn LT, Wriston JC Jr. Tumor inhibitory effect of 1-asparaginase from Escherichia coli. Arch Biochem Biophys 1964;105:450-2.

18. Makky EA, Ong JJ, Karim R, Lee, CM. Production and optimization of L-asparaginase by Bacillus sp. KK2S4 from corn cob. Afr J Biotechnol 2013;12:2654-8

19. Indira K, Jayaprabha N, Balakrishnan S, Arulmoorthy P, Srinivasan M. Production, purification and characterization of extracellular L-asparaginase from salt marsh fungal endophytes. World J Pharm Pharma Sci 2015;4:663-77.

20. Imada A, Igarasi S, Nakahama $K$, Isona $M$. Asparaginase and glutaminase activities of microorganisms. J Gen App Microb 1973;76:85-99.

21. Laemmli UK. Cleavage of structural proteins during the assembly of the head of bacteriophage T4. Nature 1970;227:680-5.

22. Sekar S, Seetaramswamy S, Gandhimathi S, Laxmanadoss M, Perumal P. Synthesis and in-vitro anticancer activity of some novel bisbenzothiazole derivatives. Int J Curr Pharm Res 2013;5:63-4.

23. Wang J, Wilcken DE, Wang XL. Cigarette smoke activates caspase-3 to induce apoptosis of human umbilical venous endothelial cells. Mol Genet Metab 2001;72:82-8.

24. Jayaramam A, Thandeeswaran M, Mahendran R, Kiran GK, Nawaz AA,
Palaniswamy M. Screening and production of anticarcinogenic enzyme from Escherichia coli CTLS20: L-asparaginase. Int J Pharm Pharm Sci 2016;8:244-8

25. Upadhyay R, Saxena A, Kango, N. Screening and production of tumor inhibitory L-asparaginase by bacteria isolated from soil. Asian J Pharm Clin Res 2012;5:135-7.

26. Jain R, Zaidi KU, Verma Y, Saxena P. L-asparaginase: A promising enzyme for treatment of acute lymphoblastic leukiemia. Peoples J Sci Res 2012;5:29-35.

27. Patil RC, Jadhav BL. Screening and optimization of L-asparaginase production from Bacillus species. J Biotech Biochem 2017;3:32-6.

28. Jha KS, Sinha KR, Singh RH. Production, purification and kinetic characterization of L-asparaginase from Pseudomonas fluorescens. Int J Pharm Pharm Sci 2015; 7:135-8.

29. Prakasham RS, Rao ChS, Rao RS, Lakshmi GS, Sarma PN. L-asparaginase production by isolated Staphylococcus sp.-6A: Design of experiment considering interaction effect for process parameter optimization. J Appl Microbiol 2007;102:1382-91.

30. Ghosh S, Murthy S, Govindasamy S, Chandrasekaran M. Optimization of L-asparaginase production by Serratia marcescens (NCIM 2919) under solid state fermentation using coconut oil cake. Sustain Chem Process 2013;1:9.

31. Manna S, Sinha A, Sadhukhan R, Chakrabarty SL. Purification, characterization and antitumor activity of L-asparaginase isolated from Pseudomonas stutzeri MB-405. Curr Microbiol 1995;30:291-8.

32. Lai L, Tsai TH, Wang TC, Cheng TY. The influence of culturing environments on lovastatin production by Aspergillus terrusin submerged cultures. Enzyme Microb Technol 2005;66:737-48.

33. Narayana KJ, Kumar KG, Vijayalakshmi M. L-asparaginase production by Streptomyces albidoflavus. Indian J Microbiol 2008;48:331-6.

34. Kumar P, Thangabalan B, Venkata R, Vadivel K. Optimization of parameters for the production of L-asparaginase by Serratia marcescens. J Pharm Biomed Sci 2011;2011:7

35. Akilandeswari K, Kavitha K, Vijayalakshi M. Production of bioactive enzyme L-asparaginase from fungal isolates of water samples through submerged fermentation. Int J Pharm Pharm Sci 2012;4:363-6.

36. Neelima D, Prachi C, Manasi A. Studies on optimization of growth parameters for L-asparaginase production by Streptomyces ginsengisoli. Sci World J 2014;2014:6

37. Stanbury PF, Whitaker A, Hall SJ. An introduction to fermentation processes. In: Principles of Fermentation Technology. $2^{\text {nd }}$ ed. Oxford: Butterworth Heinemann; 2000.

38. Susmita S, Mandal SK. Production purification and characterization of extracellular anti-leukaemic L-asparaginase from isolated Bacillus subtilis using solid state fermentation. Int J Appl Biol Pharm Technol 2013;4:89-99

39. Soniyamby AR, Lalitha S, Praveesh BV, Priyadarshini V. Isolation, production and anti-tumour activity of L-asparaginase of Penicillium sp. Int J Microbiol Res 2011;2:38-42.

40. El Shobaky A, Abbas AM, Askar NS. Production, purification and characterization of extracellular 1-asparaginase from Erwinia carotovora. Int J Bioassays 2014;3:3553-9.

41. Varalakshmi V. L-asparaginase, an enzyme of medicinal value. Int $\mathbf{J}$ Green Herb Chem 2013;2:544-54.

42. Athira RN, Elizebeth T, Narendra T, Ahmed ST. Investigation on the production of L-glutaminase from Pseudomonas stutzeri strain under solid state fermentation using various agro residues. J Drug Deliv Ther 2014:4:81-5

43. Mohamed FH. Molecular investigation and anticancer properties of purified L-asparaginase from E. coli isolate against, $\mathrm{CaCo} 2, \mathrm{MCF} 7$ and PC3 cell lines. Am J PharmTech Res 2014;4:308-22.

44. Prista A, Kyridio DA. L-asparaginase of Thermo thermophilus: Purification, properties and identification of essential amino acids for catalytic activity. Mol Cell Biochem 2001;216:93-101.

45. Bhat M, Marar T. Cytotoxic effect of purified L-asparaginase from Salinicoccus sp. M KJ997975. Int J Curr Microbiol App Sci 2015;4:701-12.

46. Abakumova OIu, Podobed OV, Karalkin PA, Kondakova LI, Sokolov NN. Antitumor activity of L-asparaginase from Erwinia carotovora from against different leukemic and solid tumours cell lines. Biomed Khim 2013;59:498-513 